\title{
Probiotics: Evidence of Oral Health Implications
}

\author{
Jukka H. Meurman ${ }^{1}$, Iva V. Stamatova ${ }^{2}$ \\ ${ }^{1}$ Department of Oral and Maxillofacial Diseases, University of Helsinki and Helsinki University Hospital, Helsinki, Finland \\ 2 Department of Restorative Dentistry, Faculty of Dental Medicine, Medical University of Plovdiv, Plovdiv, Bulgaria
}

\section{Correspondence: \\ Jukka H. Meurman, Department of Oral and Maxillofacial Diseases, University of Helsinki and Helsinki University Hospital, PB 63 (Haart- maninkatu 8 Biomedicum), 00014 Helsinki, Finland. \\ E-Mail: jukka.meurman@helsinki.fi Tel: +358504270338}

Received: 02 Nov 2016

Accepted: 27 July 2017

Published Online: 12 Sep 2017

Published: 30 March 2018

Key words: probiotics, oral biofilm, dental caries, periodontal disease, halitosis

Citation: Meurman JH, Stamatova IV. Probiotics: evidence of oral health implications. Folia Med (Plovdiv) 2018;60(1):21-9.

doi: 10.1515/folmed-2017-0080
The prevalence of common oral diseases, such as dental caries, periodontal diseases and oral candidiasis remains high in the general population. Various preventive strategies have been proposed and included in national health programs promoting oral health. Interest in probiotics in light of oral health has gradually evolved as attractive means in prevention of oral infectious diseases. The aim of the present review is to outline the current evidence on the role of probiotic species on oral health parameters and their beneficial role in contributing to healthier oral environment.

\section{INTRODUCTION}

Oral health is a vital component of health. World Health Organization defines it as a state of being free from chronic mouth and facial pain, oral and throat cancer, oral sores, birth defects such as cleft lip and palate, periodontal (gum) disease, tooth decay and tooth loss, and other diseases and disorders that affect the oral cavity. ${ }^{1}$ Global health preventive programs adopted worldwide have substantially contributed to reducing the extent and the severity of common oral diseases. Yet the prevalence of periodontal diseases and caries, both having microbial components in their etiology, remain high. Caries affects practically everyone in the global population at some stages of life while $15-35 \%$ of the adult population in industrialized countries is estimated to have periodontitis. ${ }^{2}$

The role of host microbiota in individual's health has been developing as a concept for more than a century. In the early 1900s, Bond Stow emphasized the significance of Lactobacillus bulgaricus on autointoxication and its importance on balancing gut health. ${ }^{3}$ The theory of Nobel laureate Ilya Metchnikoff (Fig. 1), that "we fight microbe with microbe"4) has attracted numerous followers who have presented clinical evidence on the role of lactic acid bacteria administration and their control on autointoxication-related mental conditions. However, this theory has been seriously discredited for several decades by famous supporters from the United States like Alvarez and Donaldson who 'debunked' autointoxication. ${ }^{5}$ The rapid scientific and technological advances in the new millennium have led to paradigm shift in understanding the relevance of entire body microbiome to human health and well-being. The role of beneficial healthy bacteria has been related to numerous pathological conditions of the gastrointestinal tract, skin, respiratory system and even mental health. Probiotics, which exert their health effect when digested in certain quantities, are able to promote health either directly or through their influence on other gut 

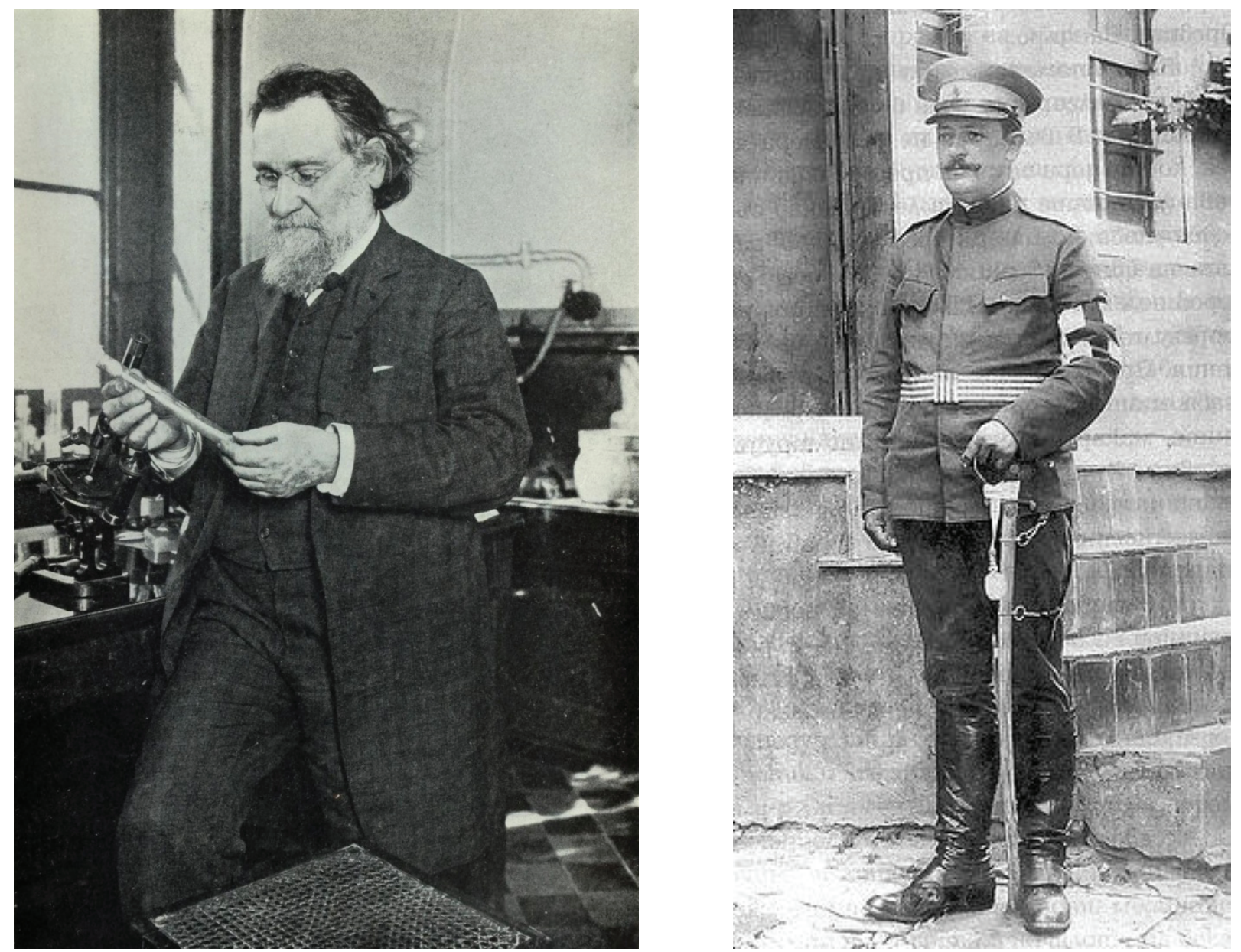

Figure 1. Ilya Metchnikoff, who laid the foundations of modern probiotics, and Stamen Grigorov, who isolated Lactobacillus bulgaricus, the main yoghurt starter.

microbes. ${ }^{6}$ The main mode of probiotic activity is ascribed to their influence on systemic cytokines, oxidative stress, and inflammatory markers upon oral consumption. ${ }^{7}$

Probiotics and their role on oral health has been proposed at the turn of the century and the reader is referred to two comprehensive review articles published in 2005 outlining the main scope and clinical relevance of healthy bacteria in the mouth..$^{8,9}$ The aim of the present review was to outline and discuss the advances in probiotic research in relation to prevention and management of common oral diseases. Table 1 lists probiotic species used in clinical trials in the field of dentistry.

\section{PROBIOTICS AND DENTAL CARIES}

Dental caries, although preventable, remains one of the most prevalent oral diseases in children and adults worldwide. Fernando et al. ${ }^{10}$ have suggested that dental caries in children could be a result of possible interaction of risk factors such as maternal characteristics, environment, child's individual factors and epigenetics. Sugar and sugar-rich diet have been the main culprits for the development of carious lesions. A shift from the caries-promoting bacterium Streptococcus mutans only towards a more complex acid-tolerant consortium of oral bacteria leading to disease has been adopted lately. Molecular microbiological methods have shown that even with a sugar-rich diet a much broader spectrum of acidogenic microbes is found in dental biofilm. ${ }^{11}$ Prevention of tooth decay by solely targeting S. mutans or by mainly limiting sugar intake is easily doomed to be inefficient in affecting disease progression. A more complex multidisciplinary approach including, for example, control of biofilm composition, control of dietary sugars in oral biofilm, and prolonged fluoride release, may be needed for caries control. Bacteriotherapy has emerged as such an alternative preventive measure which could target and tailor 
Table 1. Probiotic species used in clinical trials to target oral diseases/conditions

\begin{tabular}{|c|c|c|c|c|}
\hline Species & Condition & $\begin{array}{l}\text { Number of } \\
\text { subjects }\end{array}$ & $\begin{array}{c}\text { Vehicle of } \\
\text { administration }\end{array}$ & Reference \\
\hline L. rhamnosus & Caries prevention & 261 & milk & Rodriguez et al. 2016 \\
\hline L. reuteri & Early carious lesions & 36 & tablet & Keller at al. 2014 \\
\hline B. lactis & Caries prevention & 106 & tablet & Taipale et al. 2012 \\
\hline L. rhamnosus & Root caries & 160 & milk & Petersson et al. 2011 \\
\hline L. reuteri & Chronic periodontitis & 40 & lozenge & Tekce et al. 2015 \\
\hline L. reuteri & Gingivitis & 40 & tablet & Iniesta et al. 2012 \\
\hline L. salivarius & Halitosis & 20 & tablet & Iwamoto et al. 2010 \\
\hline L.salivarius & Prevention of periodontitis & 66 & tablet & Shimauchi et al. 2008 \\
\hline $\begin{array}{l}\text { B. longum, } S \text {. } \\
\text { thermophilus, } \\
\text { L. bulgaricus }\end{array}$ & $\begin{array}{l}\text { Candida-associated sto- } \\
\text { matitis }\end{array}$ & 65 & mixture & Li et al. 2014 \\
\hline L. rhamnosus & Candida prevention & 276 & cheese & Hatakka et al. 2007 \\
\hline L. brevis & Halitosis & 20 & lozenge & Marchetti et al. 2015 \\
\hline L. reuteri & Halitosis & 25 & chewing gum & Keller et al. 2012 \\
\hline L. reuteri & $\begin{array}{l}\text { Alteration to oral micro- } \\
\text { biotia }\end{array}$ & 44 & lozenge & Romani Vestman et al. 2015 \\
\hline
\end{tabular}

oral biofilm composition towards healthier microbial community. The use of in vitro and in silico biofilm models has allowed studies on bacteria in their similar-to-natural habitat, and respective changes in their habitat, to be investigated in more detail thus leading to more reliable outcomes. ${ }^{12}$

A primary requirement for a probiotic candidate is for that agent to establish itself in the respective environment. Our in vitro studies have shown that the probiotic Lactobacillus rhamnosus GG (LGG) could grow in dual- and multi-species oral biofilms affecting to various degrees the number of $S$. sanguinis and S. mutans in 4- and 2-species biofilm models, respectively. ${ }^{13}$ This integration of extrinsic probiotic species in oral community could be attributed to good adhesion properties and/or competition for binding sites with other species, as well as inhibitory activity against other members of the oral biofilm. Teanpaisan and coworkers have shown in vitro that caries pathogens could be effectively inhibited by oral lactobacilli with
Lactobacillus SD1-SD6 possessing the strongest inhibitory effect against $S$. mutans and $S$. sobrinus. ${ }^{14}$

LGG in different carriers, such as milk and cheese, has shown caries reducing effect in children. ${ }^{15,16}$ Caries preventive effect of LGG could be due to improved salivary buffering capacity and reduction of $S$. mutans counts. ${ }^{17}$ Salivary buffering capacity has also been observed to increase when healthy volunteers were given a probiotic tablet containing L. salivarius, thus allowing the authors to conclude that probiotic administration may lead to increased resistance to caries risk factors. ${ }^{18}$ Caries preventive effect of probiotics correlates with the time of their administration. Stensson et al. ${ }^{19}$ reported reduced caries prevalence and gingivitis score in primary dentition in 9-year-olds when the children had been given $L$. reuteri from birth and through their first year of life. Bifidobacterium animalis subsp. lactis BB-12 and L. paracasei F19, conversely, had no effect on caries occurrence if provided in infancy. ${ }^{20,21}$ Extrinsic probiotics rarely do establish 
themselves in the mouth, but although transient, their presence may affect re-colonization of mutans streptococci after full-mouth disinfection as shown with $L$. reuteri. ${ }^{22,23}$ Except for their caries preventive potential, L. reuteri and L. rhamnosus have been tested to affect pre-existing carious lesions. No adverse effects were detected by administering $L$. reuteri but its intake insubstantially affected initial carious lesions. ${ }^{24}$ However, a different outcome with reversal of primary root caries in healthy adults has been achieved with milk supplemented with L. rhamnosusmech and fluoride. ${ }^{25}$

To conclude, the effect of probiotics on dental caries remains species-dependent and results differ between studies. More robust randomized clinical trials are needed before a universal probiotic strain, or possibly a combination of species, is found for the purposes of caries prevention and control.

\section{PROBIOTICS AND PERIODONTAL DISEASES}

Periodontal diseases including gingivitis and periodontitis originate in the presence of susceptible host challenged by the burden of pathogens in oral biofilm. They are clinically manifested by bleeding on probing, swelling, color alterations, pain, and in advanced stages tooth mobility is the leading symptom. Scaling and root planing and deep pocket debridement are primary treatment strategies which allow significant reduction of aggressive periopathogens. Although removing plaque by mechanical surface instrumentation is reliable and efficient treatment modality, the pocket re-colonization is highly unpredictable. In this regard, probiotics or beneficial microbes may find their place in tailoring treatment outcome after routine periodontal treatment. The periodontal pathogens in supra- and subgingival biofilm could be substantially reduced after probiotic lactobacilli administration as demonstrated by Mayanagi et al. ${ }^{26}$

In subjects who have been clinically diagnosed with mild or moderate gingivitis probiotic administration is shown to decrease the volume of gingival crevicular fluid and bleeding on probing; clinical parameters such as gingival and plaque indices have also been positively affected..$^{27,28}$ The observed changes are related to the reduced concentrations of inflammatory cytokines such as TNF- $\alpha$ and IL-8, caused by probiotics. The reduction in the number of periodontal pathogens after $L$. reuteri administration unequivocally contributed to improved parameters of gingival health. ${ }^{29}$ Experimental gingivitis in healthy subjects, depending on the probiotic species tested, may show favorable outcome in terms of lower amount of gingival crevicular fluid, less bleeding on probing, lower elastase and MMP-3 activities. ${ }^{30,31}$ However, daily intake of probiotic lozenges was not a winning strategy for experimental gingivitis when seven inflammatory mediators were measured. ${ }^{32}$

The most commonly used probiotic species in chronic periodontitis patients so far is L. reuteri. It has been a useful adjunct to scaling and root planing when given as a lozenge once or twice daily. Lowering plaque index, gingival index, probing pocket depth and bleeding were the observed treatment outcomes. ${ }^{33,34}$ Again, the anticipated mechanisms of probiotic activity were associated with reduced numbers of periodontal pathogens, such as Porphyromonas gingivalis, and lower concentrations of TNF- $\alpha$, IL-1 $\beta$ and IL-17 in gingival crevicular fluid. ${ }^{35,36}$

An emerging problem with the growing number of dental implants placed in general population is the occurrence of peri-implantitis and peri-implant mucositis which in their origin also are microbemediated. Attempt to use probiotics to combat such treatment complications has also been made. However, in these cases there is no clinical evidence to justify the use of probiotic supplements in addition to mechanical debridement and oral hygiene reinforcement. ${ }^{37}$ As regards peri-implantitis, more studies with probiotic supplementation are indeed called for. In general, scientific evidence on probiotics vs. periodontal diseases still remains weak.

\section{PROBIOTICS AND ORAL CANDIDA INFECTIONS}

Another reasonably well explored field of probiotic applications is the chronic Candia infections of the soft tissues in the mouth. Candida species most commonly isolated from the oral cavity include $C$. albicans, C. glabrata, C. krusei, C. parapsilosis and $C$. tropicalis. The growing antifungal resistance is becoming a serious problem worldwide and new strategies to combat pathogenic fungi in biofilm structures have been sought. In vitro studies have shown various inhibitory activity against oral Candida by different commercially available probiotic lactobacilli, with strongest inhibitory effect observed with LGG. ${ }^{38}$ In an animal model study $S$. salivarius $\mathrm{K} 12$, a nonpathogenic commensal oral probiotic microorganism, significantly protected the mice from severe candidiasis by inhibiting the process of invasion of $C$. albicans into mucous surfaces or its adhesion to denture acrylic resins by mechanisms not associated with the antimicrobial 
activity of the bacteriocin. ${ }^{39}$ Lactobacillus casei and Bifidobacterium breve in yoghurt drink positively affect secretory $\operatorname{IgA}$ levels in saliva and significant reduction in Candida and non-Candida species has been observed in the oral cavity of elderly. ${ }^{40}$ Frail elderly people living in nursing homes are among individuals highly susceptible to fungal infections. A L. reuteri lozenge given twice a day for 12 weeks led to a significant reduction of Candida counts in the oral cavities of elderly, although no notable effects on plaque index and bleeding on probing were defined. ${ }^{41}$ Similarly, probiotic combination of Propionibacter freudenreichii and LGG given in cheese reduced the risk for high salivary Candida counts by $75 \%$ compared with placebo cheese in a short-term intervention study on the elderly. ${ }^{42}$ However, the true value of probiotics in controlling oral Candida is still an open question.

\section{PROBIOTICS AND HALITOSIS}

Halitosis, or the unpleasant odour exhaled through the mouth, is a multifactorial condition which may have oral and/or non-oral origins. ${ }^{43,44}$ It is mainly attributed to biofilm accumulation on the dorsum of the tongue, the interdental spaces, and chronic inflammatory diseases of the periodontium. The prevalence of halitosis varies with estimated range between $22 \%$ to $50 \%$ in populations. ${ }^{45-49}$

Volatile sulphur compounds (VSC) like hydrogen sulphide and methyl mercaptans and other additional odours such as indole, skatole, putrescine and cadaverine are byproducts of food degradation by halitosis-producing microorganisms. ${ }^{50} \mathrm{~A}$ rich source of VSC is the periodontal pocket densely populated by Fusobacterium nucleatum, P. gingivalis, Prevotella intermedia, Tannerella forsythia, Treponema denticola, Micromonas micros, Campylobacter rectus, and Eikenella corrodens. ${ }^{51-53}$ The intensity of clinical bad breath has been correlated directly to periodontal health status. ${ }^{54}$ Nevertheless, true evidence of such relationship has been questionable ${ }^{54,55}$, and tongue microbiota may play a greater role in terms of oral malodor in comparison to subgingival bacteria. ${ }^{56-58}$ Halitosis could also be associated with dietary habits and consumption of foods like garlic, onions or spiced foods is a well understood reason for this. Certain diseases, such as diabetes and uremia, and medications could also contribute to bad breath. ${ }^{59-61}$

Halitosis affects to various degrees key aspects of person's quality of life reflecting in social relationships and emotional well-being. Treatment of halitosis is achievable once its etiology is properly diagnosed. Self-care products such as chewing gums, mouthwashes, mouth sprays and toothpastes can mask temporarily the unpleasant odor and improve the satisfaction of the individual. However, the emphasis remains on professional treatment and strategies at reduction and/or elimination of VSC producing microorganisms.

Burton et al. ${ }^{62}$ were the first to address the potential of oral probiotics in reduction of halitosis. By administering S. salivarius K12 in lozenges after initial chlorhexidine rinse, eight out of 13 healthy individuals maintained reduced breath levels of VSCs for at least 2 weeks. Pre-emptive colonization of the oral cavity with competitive commensal bacteria following mechanical and chemical pretreatment has been the aim of Burton at al. ${ }^{63}$ when combating halitosis with $S$. salivarius K12. Additionally, salivaricin production by probiotic species could cross-stimulate salivaricin production by other pre-existing members of the host microbiota, thus establishing lower levels of VSC. Inhibitory activity of S. salivarius K12 on Gram-positive species involved in halitosis is another mode of activity to be utilized when targeting bad breath. ${ }^{64} \mathrm{~A}$ cross-over trial including 23 participants has shown L. salivarius WB21 to have a positive effect on oral malodor parameters by using organoleptic test score. ${ }^{65}$ Moreover, the same species has shown beneficial effects on bleeding on probing from the periodontal pocket. Administering probiotics with chewing gums could also reduce bacteria that produce malodorous compounds other than VSCs as demonstrated by Keller et al. ${ }^{66}$ After 14 days of treatment, the organoleptic scores were significantly lower in the L. reuteri group compared with placebo. In vitro testing of yogurt starter $S$. thermophilus could reduce generation of VSCs by $P$. gingivialis possibly by suppressing its growth, and the whole bacteria and the spent culture medium of $S$. thermophilus reduced emission of VSCs. ${ }^{67}$ A well-studied probiotic species L. brevis $C D 2$, however, showed no effect on halitosis after 14-day treatment in a randomized, double-blind placebo-controlled clinical trial. ${ }^{68}$ However, although potentially promising, the results from the above mentioned studies there still is no sound evidence to support recommendation of probiotics for the treatment of halitosis.

\section{CONCLUSION}

Evidence of beneficial effects of probiotics on 
oral health is accumulating. In general, the growing population awareness and demand for healthy living inevitably leads to broader availability of health-promoting foods on the market. In this field probiotics have become fashionable among the public and are marketed as one of the key elements in well-balanced general health. As here discussed, most oral health effects of probiotics have been observed after administration of strains which are not natural members of oral microbiota. Possibly a more attractive and reliable probiotic might be found among species which are natural members in the host microbiome. Screening of such probiotic candidates in human oral bacterial populations is ongoing with some evidence already available. ${ }^{69}$ Further, multi-center clinical trials with enough statistical power, and the use of high-throughput analytical tools, are needed for true evidence before the role of probiotics on oral health can be established and their use justified. Currently the evidence yet remains weak.

\section{ACKNOWLEDGEMENTS}

Writing this article was partly supported by grants from the Medical Society of Finland and the Finnish Society of Sciences and Letters.

\section{REFERENCES}

1. www.who.int

2. Socransky SS, Smith C, Haffajee AD. Subgingival microbial profiles in refractory periodontal disease. J Clin Periodontol 2002;29(2):260-8.

3. Stow B. Metchnikoff's basic principle - intestinal antisepsis through biological aids - attested by the Bacillus Bulgaricus. Med Record 1914;86(2):233-6.

4. Metchnikoff E, Williams HS. Why not live forever? Cosmopolitan 1912;53(5):436-46.

5. Bested AC, Logan AC, Selhub EM. Intestinal microbiota, probiotics and mental health: from Metchnikoff to modern advances: Part I - autointoxication revisited. Gut Pathog 2013;5(1):5.

6. Bested AC, Logan AC, Selhub EM. Intestinal microbiota, probiotics and mental health: from Metchnikoff to modern advances: part III - convergence toward clinical trials. Gut Pathog 2013;5(1):4.

7. Naruszewicz M, Johansson ML, Zapolska-Downar D, et al. Effect of Lactobacillus plantarum 299v on cardiovascular disease risk factors in smokers. Am J Clin Nutr 2002;76(6):1249-55.

8. Meurman JH. Probiotics: do they have a role in oral medicine and dentistry? Eur J Oral Sci 2005;113(3):188-96.
9. Caglar E, Kargul B, Tanboga I. Bacteriotherapy and probiotics' role on oral health. Oral Dis 2005;11(3):131-7.

10. Fernando S, Speicher DJ, Bakr MM, et al. Protocol for assessing maternal, environmental and epigenetic risk factors for dental caries in children. BMC Oral Health 2015;29(15):167.

11. Bradshaw DJ, Lynch RJ. Diet and the microbial aetiology of dental caries: new paradigms. Int Dent J 2013;63 Suppl 2:64-72.

12.ten Cate JM. Models and role models. Caries Res 2015;49 Suppl 1:3-10.

13. Jiang Q, Stamatova I, Kainulainen V, et al. Interactions between Lactobacillus rhamnosus GG and oral micro-organisms in an in vitro biofilm model. BMC Microbiol 2016;16(1):149.

14. Teanpaisan R, Piwat S, Dahlen G. Inhibitory effect of oral Lactobacillus against oral pathogens. Lett Appl Mirobiol 2011;53(4):452-9.

15. Näse L, Hatakka K, Savilahti E, et al. Effect of long-term consumption of a probiotic bacterium, Lactobacillus rhamnosus GG, in milk on dental caries and caries risk in children. Caries Res 2001;35(6):412-20.

16. Ahola AJ, Yli-Knuuttila H, Suomalainen T, et al. Short-term consumption of probiotic-containing cheese and its effect on dental caries risk factors. Arch Oral Biol 2002;47(11):799-804.

17. Glavina D, Gorseta K, Skrinjarić I, et al. Effect of LGG yoghurt on Streptococcus mutans and Lactobacillus spp. salivary counts in children. Coll Antropol 2012;36(1):129-132.

18. Nishihara T, Suzuki N, Yoneda M, et al. Effects of Lactobacillus salivarius-containing tablets on caries risk factors: a randomized open-label clinical trial. BMC Oral Health 20142 (14):110.

19. Stensson M, Koch G, Coric S, et al. Oral administration of Lactobacillus reuteri during the first year of life reduces caries prevalence in the primary dentition at 9 years of age. Caries Res 2014;48(2):111-7.

20. Taipale T, Pienihäkkinen K, Alanen P, et al. Administration of Bifidobacterium animalis subsp. lactis BB-12 in early childhood: a post-trial effect on caries occurrence at four years of age. Caries Res 2013;47(5):364-72.

21. Hasslöf P, West CE, Videhult FK, et al. Early intervention with probiotic Lactobacillus paracasei F19 has no long-term effect on caries experience. Caries Res 2013;47(6):559-65.

22.Romani Vestman N, Hasslöf P, Keller MK, et al. Lactobacillus reuteri influences regrowth of mutans streptococci after full-mouth disinfection: a double-blind, randomised controlled trial. Caries Res 2013;47(4):338-45. 
23. Keller MK, Hasslöf P, Dahlén G, et al. Probiotic supplements (Lactobacillus reuteri DSM 17938 and ATCC PTA 5289) do not affect regrowth of mutans streptococci after full-mouth disinfection with chlorhexidine: a randomized controlled multicenter trial. Caries Res 2012;46(2):140-6.

24. Keller MK, Nøhr Larsen I, Karlsson I, et al. Effect of tablets containing probiotic bacteria (Lactobacillus reuteri) on early caries lesions in adolescents: a pilot study. Benef Microbes 2014;5(4):403-7.

25.Petersson LG, Magnusson K, Hakestam U, et al. Reversal of primary root caries lesions after daily intake of milk supplemented with fluoride and probiotic lactobacilli in older adults. Acta Odontol Scand 2011;69(6):321-7.

26. Mayanagi G, Kimura M, Nakaya S, et al. Probiotic effects of orally administered Lactobacillus salivarius WB21-containing tablets on periodontopathic bacteria: a double-blinded, placebo-controlled, randomized clinical trial. J Clin Periodontol 2009;36(6):506-13.

27. Krasse P, Carlsson B, Dahl C, et al. Decreased gum bleeding and reduced gingivitis by the probiotic Lactobacillus reuteri. Swed Dent J 2006;30(2):55-60.

28. Twetman S, Derawi B, Keller M, et al. Short-term effect of chewing gums containing probiotic Lactobacillus reuteri on the levels of inflammatory mediators in gingival crevicular fluid. Acta Odontol Scand 2009;67(1):19-24.

29. Iniesta M, Herrera D, Montero E, et al. Probiotic effects of orally administered Lactobacillus reutericontaining tablets on the subgingival and salivary microbiota in patients with gingivitis. A randomized clinical trial. J Clin Periodontol 2012;39(8):736-44.

30.Staab B, Eick S, Knöfler G, et al. The influence of a probiotic milk drink on the development of gingivitis: a pilot study. J Clin Periodontol 2009;36(10):850-6.

31. Slawik S, Staufenbiel I, Schilke R, et al. Probiotics affect the clinical inflammatory parameters of experimental gingivitis in humans. Eur J Clin Nutr 2011;65(7):857-63.

32. Hallström H, Lindgren S, Yucel-Lindberg T, et al. Effect of probiotic lozenges on inflammatory reactions and oral biofilm during experimental gingivitis. Acta Odontol Scand 2013;71(3-4):828-33.

33. Tekce $\mathrm{M}$, Ince $\mathrm{G}$, Gursoy $\mathrm{H}$, et al. Clinical and microbiological effects of probiotic lozenges in the treatment of chronic periodontitis: a 1-year followup study. J Clin Periodontol 2015;42(4):363-72.

34. Vicario M, Santos A, Violant D, et al. Clinical changes in periodontal subjects with the probiotic Lactobacillus reuteri Prodentis: a preliminary randomized clinical trial. Acta Odontol Scand
2013;71(3-4):813-9.

35. Szkaradkiewicz AK, Stopa J, Karpiński TM. Effect of oral administration involving a probiotic strain of Lactobacillus reuteri on pro-inflammatory cytokine response in patient with chronic periodontitis. Arch Immunol Ther Exp (Warsz 2014;62(6):495-500.

36. Teughels W, Durukan A, Ozcelik O, et al. Clinical and microbiological effects of Lactobacillus reuteri in the treatment of chronic periodontitis: a randomised placebo-controlled study. J Clin Periodontol 2013;40(11):1025-35.

37. Hallström H, Lindgren S, Widén C, et al. Probiotic supplements and debridement of peri-implant mucositis: a randomized controlled trial. Acta Odontol Scand 2016;74(1):60-6.

38. Jiang Q, Stamatova I, Kari K, et al. Inhibitory activity in vitro of probiotic lactobacilli against oral Candida under different fermentation conditions. Benef Microbes 2015;6(3):361-8.

39. Ishijima SA, Hayama K, Burton JP, et al. Effect of Streptococcus salivarius K12 on the in vitro growth of Candida albicans and its protective effect in an oral candidiasis model. Appl Environ Microbiol 2012;78(7):2190-9.

40. Mendonça FX, Santos SS, Faria I, et al. Effects of probiotic bacteria on Candida presence and IgA anti-Candida in the oral cavity of elderly. Braz Dent J 2012;23(3):534-8.

41. Kraft-Bodi E, Jørgensen MR, Keller MK, et al. Effect of probiotic bacteria on oral Candida in frail elderly. Dent Res. 2015;94(9 Suppl):181S-186S.

42. Hatakka K, Ahola AJ, Yli-Knuuttila H, et al. Probiotics reduce the prevalence of oral candida in the elderly--a randomized controlled trial. J Dent Res 2007;86(2):125-30.

43. Oliveira-Neto JM, Sato S, Pedrazzi V. How to deal with morning bad breath: a randomised, crossover clinical trial. J Indian Soc Periodontol 2013;17(6):757-61.

44. van den Broek AM, Feenstra L, de Baat C. Areview of the current literature on aetiology and measurement methods of halitosis. J Dentistry 2007;35(8):627-35.

45. Yaegaki K, Coil JM. Examination, classification, and treatment of halitosis; clinical perspectives. J Can Dent Assoc 2000;66(5):257-61.

46. Miyazaki H, Sakao S, Katoh Y, et al. Oral malodor in the general population of Japan. In: Rosenberg M, editor. Bad Breath: Research Perspectives. Tel Aviv: Ramot Publishing; 1995. p. 119-36.

47. Meningaud JP, Bado F, Favre E, et al. [Halitosis in 1999]. Revue de Stomatologie et de Chirurgie Maxillo-Faciale 1999;100(5):240-4 [Article in French]. 
48. Quirynen M, Dadamio J, Van den Velde S, et al. Characteristics of 2000 patients who visited a halitosis clinic. J Clin Periodontol 2009;36(11):970-5.

49. Akaji EA, Folaranmi N,Ashiwaju O. Halitosis: a review of the literature on its prevalence, impact and control. Oral Health \& Preventive Dentistry 2014;12(4):297-304.

50.Kleinberg I, Codipilly M. The biological basis of oral malodor formation. In: Rosenberg $\mathrm{M}$, editor. Bad Breath: Research Perspectives. Tel Aviv: Ramot Publishing; 1995. p. 13-40.

51. De Boever EH, Loesche, WJ. Assessing the contribution of anaerobic microflora of the tongue to oral malodor. J Am Dent Assoc 1995;126(6):1384-93.

52. Khaira N, Palmer RM, Wilson RF, et al. Production of volatile sulphur compounds in diseased periodontal pockets is significantly increased in smokers. Oral Dis 2000;6(4):371-5.

53. Loesche WJ, Kazor C. Microbiology and treatment of halitosis. Periodontol 2000 2002;28(5):256-79.

54. Bosy GV, Kulkarni M, Rosenberg CAG, et al. Relationship of oral malodor to periodontitis: evidence of independence in discrete subpopulations. J Periodontol 1994;65(1):37-46.

55. Sharma NC, Galustians HJ, Qaquish J, et al. The clinical effectiveness of a dentifrice containing triclosan and a copolymer for controlling breath odor measured organoleptically twelve hours after toothbrushing. J Clin Dent 1999;10(2):131-4.

56. Nakano Y, Yoshimura M, Koga T. Correlation between oral malodor and periodontal bacteria. Microbes Infect 2002;4(9):679-83.

57. Miyazaki H, Sakao S, Katoh Y, et al. Correlation between volatile sulphur compounds and certain oral health measurements in the general population. J Periodontol 1995;66(8):679-84.

58. Yaegaki K, Sanada K. Volatile sulfur compounds in mouth air from clinically healthy subjects and patients with periodontal disease. J Periodontol Res 1992;27(2):233-8.

59. Ciçek Y, Orbak R, Tezel A, et al. Effect of tongue brushing on oral malodor in adolescents. Pediatr Int 2003;45(6):719-23.
60. Lu DP. Halitosis: an etiologic classification, a treatment approach, and prevention. Oral Surg Oral Med Oral Pathol. 1982;54(5):521-6.

61.Al-Zahrani MS, Zawawi KH, Austah ON, et al. Self-reported halitosis in relation to glycated hemoglobin level in diabetic patients. Open Dent J 2011;5(2):154-7.

62. Burton JP, Chilcott CN, Tagg JR. The rationale and potential for the reduction of oral malodour using Streptococcus salivarius probiotics. Oral Dis 2005;11 Suppl 1:29-31.

63. Burton JP, Chilcott CN, Moore CJ, et al. A preliminary study of the effect of a probiotic Streptococcus salivarius K12 on oral malodour parameters. J Applied Microbiol 2006;100(6):754-64.

64. Masdea L, Kulik EM, Hauser-Gerspach I, et al. Antimicrobial activity of Streptococcus salivarius K12 on bacteria involved in oral malodour. Arch Oral Biol 2012;57(5):1041-7.

65. Iwamoto T, Suzuki N, Tanabe K, et al. Effect of Lactobacillus salivarius WB21 on halitosis and oral health: an open label pilot trial. Oral Surg Oral Med Oral Pathol Oral Radiol Endod 2010;110(2):201-8.

66. Keller MK, Bardow A, Jensdottir T, et al. Effect of chewing gums containing the probiotic bacterium Lactobacillus reuteri on oral malodour. Acta Odontol Scand 2012;70(3):246-50.

67. Romani Vestman N, Chen T, et al. Oral microbiota shift after 12-week supplementation with Lactobacillus reuteri DSM 17938 and PTA 5289: a randomized controlled trial. PLoS One 2015;10(5):e0125812.

68. Marchetti E, Tecco S, Santonico M, et al. Multi-sensor approach for the monitoring of halitosis treatment via Lactobacillus brevis (CD2)-containing lozenges - a randomized, double-blind placebo-controlled clinical trial. Sensors 2015;15(8):19583-96.

69. Terai T, Okumura T, Imai S, et al. Screening of probiotic candidates in human oral bacteria for the prevention of dental disease. PLoS One 2015;10(6):432-8.

70.Li D, Li Q, Liu C, et al. Efficacy and safety of probiotics in the treatment of Candida-associated stomatitis. Mycoses 2014;57(3):141-6. 


\title{
Пробиотики: Доказательства о последствиях для стоматологического здоровья
}

\author{
Юкка Х. Марман ${ }^{1}$, Ива В. Стаматова ${ }^{2}$ \\ ${ }^{1}$ Кафедра стоматологических и челюстно-лицевых заболеваний, Университет Хельсинки и Университетская больница \\ Хельсинки, Хельсинки, Финляндия \\ 2 Кафедра восстановительной стоматологии, Факультет дентальной медицины, Медицинский университет - Пловдив, \\ Болгария
}

\begin{abstract}
Адрес для корреспонденции: Юкка Х. Марман, Кафедра стоматологических и челюстно-лицевых заболеваний, Университет Хельсинки и Университетская больница Хельсинки, РВ 63 („Хаартманинкату" 8 Биомедикум), 00014, Хельсинки, Финляндия

E-Mail: jukka.meurman@helsinki.fi Tel: +358504270338
\end{abstract}

Дата получения: 02 ноября 2016

Дата приемки: 27 июля 2017

Дата онлайн публикации: 12 сентября 2017

Дата публикации: 30 марта 2018

Ключевые слова: пробиотики, зубной налёт, зубной кариес, пародонтоз, халитоз

\section{Образец цитирования:}

Meurman JH, Stamatova IV. Probiotics: evidence of oral health implications. Folia Med (Plovdiv) 2018;60(2): 21-9.

doi: 10.1515/folmed-2017-0080
Распространение таких наиболее часто встречающихся стоматологических заболеваний как зубной кариес, пародонтоз и оральный кандидоз остаётся по-прежнему высоким среди населения. Большое количество разных стратегий для профилактики данных заболеваний были предложены и включены в национальные программы здравоохранения, нацеленные на стоматологическое здоровье. Интерес к пробиотикам в свете стоматологического здоровья постепенно возрос в качестве привлекательного средства для профилактики стоматологических инфекционных заболеваний. Целью настоящего обозрения является рассмотрение современных доказательств о роли пробиотических штаммов в отношении параметров стоматологического здоровья и их полезной роли в отношении более здоровой среды полости рта 